REFLEKSI HUKUM

Jurnal Ilmu Hukum
p-ISSN 2541-4984 | e-ISSN 2541-5417

Volume 3 Nomor 2, April, Halaman 145-160

DOI: https://doi.org/10.24246/jrh.2019.v3.i2.p145-160

Open access at: http://ejournal.uksw.edu/refleksihukum

Penerbit: Fakultas Hukum Universitas Kristen Satya Wacana

\title{
PERLINDUNGAN HUKUM TERHADAP KEAMANAN DATA KONSUMEN FINANCIAL TECHNOLOGY DI INDONESIA
}

\author{
Kornelius Benuf, Siti Mahmudah, Ery Agus Priyono \\ Fakultas Hukum Universitas Diponegoro \\ Korespondensi: korneliusbenuf@gmail.com
}

\begin{abstract}
Abstrak
Penelitian ini bertujuan untuk mengetahui perlindungan hukum terhadap keamanan data konsumen dalam bisnis Fintech di Indonesia, berdasarkan Peraturan Otoritas Jasa Keuangan, dan peraturan terkait. Metode pendekatan yang digunakan adalah yuridis normatif. Hasil penelitian menyatakan bahwa, para pihak dalam bisnis Fintech terdiri dari penyelenggara bisnis Fintech (produsen) dan pengguna Fintech (konsumen). Hubungan para pihak dalam bisnis Fintech terjadi karena adanya perjanjian elektronik. Perlindungan terhadap data pribadi konsumen Fintech diatur dalam Peraturan Menteri Komunikasi dan Informatika, Peraturan Bank Indonesia dan Peraturan Otoritas Jasa Keuangan. Mengenai data yang harus dilindungi telah diatur dalam Surat Edaran Otoritas Jasa Keuangan.
\end{abstract}

Kata Kunci: Fintech; Hubungan Hukum; Perlindungan Hukum; Data Pribadi Konsumen.

\begin{abstract}
Absract
The aim of this study is to determine legal protection of consumer data security in Indonesia Fintech business based on Financial Service Authority (Otoritas Jasa Keuangan-OJK) Regulation and other related ordinance. The approach method used in this study is normative juridicial. The study result explains that the parties of Fintech business is consisted of Fintech organizer (producer) and Fintech user (consumer). The relation among the parties is created due to an electronic contract. Basically, the protection of Fintech consumer personal data is regulated in Communication and Information Minister Regulation, Bank Indonesia Regulation, and Financial Service Authority Regulation. In addition, the protection of data was regulated in Financial Service Authority Circular Letter.
\end{abstract}

Keywords: Fintech; Legal Relations; Legal Protection; Consumer Personal Data. 


\section{PENDAHULUAN}

Perkembangan teknologi informasi utamanya interconnection-networking (internet), membawa pengaruh besar di seluruh lini kehidupan manusia. Kehidupan modern saat ini sangat bergantung pada kemajuan teknologi. ${ }^{1}$ Asosiasi Penyedia Jasa Internet Indonesia (APJII) pada tahun 2017 menyatakan jumlah pengguna internet di Indonesia mencapai 143, 26 juta jiwa. Tingginya pengguna jasa internet di Indonesia juga berdampak pada tumbuh pesatnya perusahaan Fintech. Kepala Sub Bagian Perizinan Fintech Direktorat Pengaturan, Pengawasan, dan Perizinan Fintech Otoritas Jasa Keuangan (OJK), Alvin Taulu mengatakan, bahwa hingga tahun 2018 total transaksi dari industri fintech peer to peer (P2P) lending mencapai Rp 26 triliun, ${ }^{2}$ data lain bisa dilihat dari jumlah perusahaan Fintech berizin dan terdaftar di OJK per Januari 2019, yang berjumlah 99 perusahaan, ${ }^{3}$ sebelumnya per Desember 2018 jumlah perusahaan Fintech terdaftar adalah 88 perusahaan. ${ }^{4}$

Pesatnya pertumbuhan perusahaan Fintech juga dikarenakan Fintech menawarkan beragam layanan keuangan yang sangat membantu masyarakat dalam menjalankan roda perekonomian menjadi lebih efektif dan efisien khususnya sektor keuangan. ${ }^{5}$ Namun dalam pelaksanaannya ternyata bisnis Fintech memiliki potensi risiko, setidaknya ada dua potensi risiko yaitu risiko keamanan data konsumen dan risiko kesalahan transaksi. ${ }^{6}$ Kedua risiko tersebut kemudian akan membawa kerugian pada masing-masing pihak dalam bisnis Fintech. Timbulnya aksi kejahatan online seperti penyadapan, pembobolan dan cybercrime dalam transaksi finansial perbankan menjadikan masyarakat menjadi ragu untuk melakukan transaksi online. ${ }^{7}$

Penelitian ini akan memfokuskan pada risiko keamanan data konsumen dalam bisnis Fintech di Indonesia. Perlindungan terhadap data pribadi konsumen Fintech mutlak diperlukan, harus ada aturan yang menjamin kerahasiaan data pribadi konsumen dalam bisnis Fintech (required regulatory reform regarding the information technology, particularly on the protection of misuse of personal

Barda Nawawi Arief 'Kebijakan Penanggulangan Cyber Crime dan Cyber Sex' (2005) 1 Jurnal Law Reform 11, 11.

2 Danang Sugianto, 'Transaksi Fintech di Indonesia Tembus Rp 26 Triliun' (2019) <https://fin ance.detik.com/berita-ekonomi-bisnis/d-4445880/transaksi-fintech-di-indonesia-tembus-rp-26triliun> diakses 28 Februari 2019.

3 Publikasi OJK, 'Penyelenggara Fintech Terdaftar di OJK per Februari 2019' (2019) <https://www.ojk.go.id/id/berita-dan-kegiatan/publikasi/Pages/Penyelenggara-Fintech-Terdaft ar-di-OJK-per-Februari-2019.aspx> diakses 28 Februari 2019.

4 Publikasi OJK, 'Penyelenggara Fintech Terdaftar di OJK per Desember 2018' (2018) <https://www.ojk.go.id/id/berita-dan-kegiatan/publikasi/Pages/Penyelenggara-Fintech-Terdaft ar-di-OJK-per-Desember-2018.aspx> diakses 21 Januari 2019.

$5 \quad$ Farah Margaretha, 'Dampak Elektronik Banking Terhadap Kinerja Perbankan Indonesia' (2015) 19 Jurnal Keuangan dan Perbankan 514, 516.

$6 \quad$ OJK, Kajian Perlindungan Konsumen Sektor Jasa Keuangan: Perlindungan Konsumen Pada Fintech (Departemen Perlindungan Konsumen OJK 2017) 28.

7 Imanuel Adhitya M. Chrismastianto, 'Analisis SWOT Implementasi Tekonologi Finansial terhadap Kualitas Layanan Perbankan di Indonesia' (2017) 20 Jurnal Ekonomi dan Bisnis 137, 148. 
data). 8 Permasalahan yang ingin dibahas yaitu: Bagaimana hubungan hukum para pihak dalam bisnis Fintech di Indonesia? Bagaimana perlindungan hukum terhadap keamanan data konsumen dalam bisnis Fintech di Indonesia?

\section{PEMBAHASAN}

\section{Pengaturan Bisnis Fintech di Indonesia}

Bisnis Fintech merupakan inovasi finansial dengan sentuhan teknologi modern, yang memanfaatkan perkembangan teknologi informasi untuk menciptakan inovasi baru di sektor jasa keuangan, yang lebih cepat dan mudah digunakan. Financial Technology is a financial product and services service through a combination of the technology platform and innovative business model (Teknologi Finansial adalah produk dan layanan jasa keuangan melalui kombinasi platform teknologi dan model bisnis yang inovatif).${ }^{9}$ Kegiatan usaha dari bisnis Fintech adalah Layanan Jasa Keuangan (selanjutnya disebut LJK) secara elektronik. Dengan demikian bisnis Fintech adalah suatu model bisnis yang menyediakan LJK dengan memanfaatkan teknologi informasi. Fintech is an innovation that involves the use of modern technology in the field of financial services. ${ }^{10}$

Jadi apabila dilihat dari sistem kegiatan usaha yang dijalankan, maka bisnis Fintech ini menjalankan sistem elektronik untuk menjalankan sistem
LJK kepada konsumennya. Sehingga bisnis Fintech terikat pada peraturan perundang-undangan tentang sistem elektronik dan peraturan tentang LJK. Oleh karena itu, bisnis Fintech diatur dan diawasi oleh Kementerian Komunikasi dan Informatika Republik Indonesia (Kemkominfo RI) sebagai regulator sistem elektronik dan Bank Indonesia serta OJK sebagai regulator sistem LJK.

\section{Pengaturan Mengenai Ruang Lingkup Bisnis Fintech}

a. Peraturan Bank Indonesia

Ruang lingkup penyelenggaraan Fintech yang diatur dalam Pasal 3 ayat (1) Peraturan Bank Indonesia (PBI) No. 19/12/PBI/ 2017 tentang Penyelenggaraan Fintech ini dikategorikan menjadi 5 (lima), yaitu:

1) Sistem pembayaran (digital payment) yang mencakup otorisasi, kliring, penyelesaian akhir, dan pelaksanaan pembayaran. Contohnya penggunaan teknologi blockchain atau distributed ledger untuk penyelenggaraan transfer dana, uang elektronik dompet elektronik dan mobile payments.

2) Pendukung pasar, merupakan Fintech yang menggunakan teknologi informasi dan/atau teknologi elektronik untuk memfasilitasi pemberian informasi yang lebih cepat dan lebih murah terkait dengan produk dan/atau LJK kepada masyarakat. Contohnya penyediaan data perbandingan

8 Lastuti Abubakar \& Tri Handayani, 'Financial Technology: Legal Challenges for Indonesia Financial Sector' (IOP Conference Series: Earth and Environmental Science 2018) 175 IOP Publishing 1, 4.

9 Buckley R. P. and Webster S., 'Fin-Tech in Developing Countries: Charting New Customer Journeys J Capco Inst J Financ Transform' (2018) 44 Journal of Financial Transformation 1, 19.

10 A. Raharjo \& T. Sudrajat (Eds.), 'Fintech Indonesia User Legal Protection in Balance Borrowing Money Based on Information Technology' (2018) 54 SHS Web of Conferences 1, 1. 
informasi produk atau LJK.

3) Manajemen investasi dan manajemen risiko. Contohnya penyediaan produk investasi online dan asuransi online.

4) Pinjaman, pembiayaan dan penyediaan modal. Contohnya layanan pinjam meminjam uang berbasis teknologi informasi (peer to peer lending) serta pembiayaan atau penggalangan dana berbasis teknologi informasi (crowdfunding).

5) Jasa finansial lainnya selain keempat hal yang sudah disebutkan sebelumnya.

b. Peraturan Otoritas Jasa Keuangan

OJK menyelenggarakan sistem pengaturan dan pengawasan yang terintegrasi terhadap keseluruhan kegiatan sektor jasa keuangan, maka bisnis Fintech juga merupakan bisnis yang diawasi oleh OJK. Pengaturan bisnis Fintech di Indonesia pertama kali dikeluarkan oleh OJK melalui Peraturan Otoritas Jasa Keuangan (POJK) No. 77/POJK.01/2016 tentang Layanan Pinjam Meminjam Uang Berbasis Teknologi Informasi. Pinjam meminjam uang berbasis teknologi informasi yang artinya startup yang menyediakan platform pinjaman secara online ${ }^{11}$ atau penyelenggaraan layanan jasa keuangan untuk mempertemukan pemberi dengan penerima pinjaman dalam rangka melakukan perjanjian pinjam meminjam dalam mata uang rupiah secara langsung melalui sistem elektronik dengan menggunakan jaringan internet.
Pengaturan dan pengawasan OJK terhadap bisnis Fintech juga diatur dalam POJK No. 13 /POJK.02/2018 tentang Inovasi Keuangan Digital di Sektor Jasa Keuangan, tujuannya untuk penyelenggaraan Inovasi Keuangan Digital (IKD) secara bertanggung jawab. Pengaturan IKD dilakukan dengan tujuan untuk mendukung pengembangan IKD yang bertanggung jawab, mendukung pemantauan IKD yang efektif, dan mendorong sinergi di dalam ekosistem digital jasa keuangan sebagaimana diatur dalam Pasal 2 ayat (1) dan (2) tentang tujuan IKD. Cakupan bisnis Fintech dalam POJK ini dibagi menjadi delapan jenis sebagaimana diatur dalam Pasal 3 yaitu: ${ }^{12}$

1) Penyelesaian transaksi, praktiknya penyelesaian transaksi biasa disebut juga dengan settlement, seperti yang terkait penyelesaian investasi.

2) Penghimpunan modal, seperti equity crowdfunding, virtual exchange and smart contract, serta alternative due diligence.

3) Pengelolaan investasi, antara lain advance algorithm, cloud computing, capabilities sharing, open source information technology, automated advice and management, social trading, dan retail algorithmic trading.

Penghimpunan dan penyaluran dana, seperti pinjam meminjam berbasis aplikasi teknologi $(P 2 P$ lending), alternative adjudication, virtual technologies, mobile 3.0 dan third-party application program ming interface.

11 Ferry Hendro Basuki \& Hartina Hussein, 'Analisis SWOT Financial Technology Pada Dunia Perbankan Di Kota Ambon (Survey Pada Bank di Kota Ambon)' (2018) 2 Jurnal Manajemen dan Bisnis 60, 66.

12 Pasal 3 POJK No. 13 /POJK.02/2018. 
4) Perasuransian, antara lain sharing economy, autonomous vehicle, digital distribution dan securitization and hedge fund.

5) Pendukung pasar, antara lain artifial inteligence/ machine learning, machine readble news, social sentiment, big data, market information platform and automated data collection and analysis.

6) Pendukung keuangan digital lainnya, antara lain social/ eco crowdfunding, islamic digital financing, ewaqf, e-zakat, robo advise dan credit scoring.

7) Aktivitas jasa keuangan lainnya, antara lain invoice trading, voucher, token, dan produk berbasis aplikasi blockchai.

Membaca aturan yang dikeluarkan oleh 2 (dua) lembaga yang telah diuraikan satu persatu di atas dapat disimpulkan bahwa ruang lingkup bisnis Fintech terdiri dari sistem pembayaran/penyelesaian transaksi (digital payment); pendukung pasar; pinjaman, pembiayaan, dan penyediaan modal/ penghimpunan modal; pengelolaan investasi; perasuransian; pendukung keuangan digital lainnya; dan aktifitas jasa keuangan lainnya. Dalam penyelenggaraannya bisnis Fintech menggunakan instrumen yaitu kontrak elektronik, sehingga harus tunduk pada aturan mengenai kontrak elektronik yang diatur dalam Undang-Undang (UU) No. 19 Tahun 2016 tentang Perubahan Atas UU No. 11 Tahun 2008 tentang Informasi dan Transaksi Elektronik (selanjutnya disebut UU ITE), khususnya Pasal 1 dan Pasal 18 UU tersebut.

\section{Pengaturan Mengenai Kontrak Bisnis Fintech oleh Kemkominfo}

Seperti telah dijelaskan sebelumnya bahwa Fintech juga menyelenggarakan sistem elektronik dalam menjalankan usahanya sehingga harus tunduk pada aturan yang dikeluarkan oleh regulator yang mengatur dan mengawasi sistem elektronik yaitu Kemkominfo RI. Kemkominfo RI mengatur dan mengawasi penyelenggaraan bisnis Fintech di Indonesia melalui UU ITE. Pasal yang secara langsung berkaitan dengan penyelenggaran bisnis Fintech adalah Pasal 1 angka 17 dan Pasal 18 yang mengatur mengenai kontrak elektronik. Kontrak elektronik adalah perjanjian para pihak yang dibuat melalui sistem elektronik.

\section{Pengaturan mengenai Perlindung- an Hukum Terhadap Data Konsumen dalam Bisnis Fintech}

a. Peraturan Menkominfo No. 20 Tahun 2016 tentang Perlindungan Data Pribadi Dalam Sistem Elektronik

Data pribadi adalah data perseorangan tertentu yang disimpan, dirawat dan dijaga kebenaran serta dilindungi kerahasiaannya. ${ }^{13}$ Perlindungan data pribadi dalam sistem elektronik mencakup perlindungan terhadap perolehan, pengumpulan, pengolahan, penganalisisan, penyimpanan, penampilan, pengumuman, pengiriman, penyebarluasan dan pemusnahan data pribadi. ${ }^{14}$ Pelaksanaan perlindungan data pribadi dalam sistem elektronik harus berdasarkan pada asas penghormatan terhadap data pribadi sebagai privasi.

Pasal 1 angka 1 Perkominfo No. 20 Tahun 2016.

Bandingkan Pasal 3 Perkominfo No. 20 Tahun 2016. 
Setiap pemilik data pribadi memiliki hak atas datanya dalam sistem elektronik. Hak-hak tersebut diatur dalam Pasal 26, yaitu: berhak atas kerahasiaan data pribadinya; mengajukan pengaduan dalam rangka penyelesaian sengketa data pribadi atas kegagalan perlindungan kerahasiaan data pribadinya oleh penyelenggara sistem elektronik kepada menteri; mendapatkan akses atau kesempatan untuk mengubah atau memperbarui data pribadinya tanpa mengganggu sistem pengelolaan data pribadi, kecuali ditentukan lain oleh ketentuan peraturan perundangundangan; mendapatkan akses atau kesempatan untuk memperoleh historis data pribadinya yang pernah diserahkan kepada penyelenggara sistem elektronik sepanjang masih sesuai dengan ketentuan peraturan perundang-undangan; dan meminta pemusnahan data perseorangan tertentu miliknya dalam sistem elektronik yang dikelola oleh penyelenggara sistem elektronik, kecuali ditentukan lain oleh ketentuan peraturan perundang-undangan.

Pengguna sistem elektronik memiliki kewajiban untuk menjaga kerahasiaan data pribadi yang diperoleh, dikumpulkan, diolah, dan dianalisisnya; menggunakan data pribadi sesuai dengan kebutuhan pengguna saja; melindungi data pribadi beserta dokumen yang memuat data pribadi tersebut dari tindakan penyalahgunaan; dan bertanggung jawab atas data pribadi yang terdapat dalam penguasaannya, baik penguasaan secara organisasi yang menjadi kewenangannya maupun perorangan, jika terjadi tindakan penyalahgunaan. ${ }^{15}$
Penyelenggara sistem elektronik memiliki kewajiban untuk melakukan sertifikasi sistem elektronik yang dikelolanya sesuai dengan ketentuan peraturan perundang-undangan; menjaga kebenaran, keabsahan, kerahasiaan, keakuratan dan relevansi serta kesesuaian dengan tujuan perolehan, pengumpulan, pengolahan, penganalisisan, penyimpanan, penampilan, pengumuman, pengiriman, penyebarluasan dan pemusnahan data pribadi; memberitahukan secara tertulis kepada pemilik data pribadi jika terjadi kegagalan perlindungan rahasia data pribadi dalam sistem elektronik yang dikelolanya; memiliki aturan internal terkait perlindungan data pribadi yang sesuai dengan ketentuan peraturan perundangundangan; menyediakan rekam jejak audit terhadap seluruh kegiatan penyelenggaraan sistem elektronik yang dikelolanya; memberikan opsi kepada pemilik data pribadi mengenai data pribadi yang dikelolanya dapat/ atau tidak dapat digunakan dan/atau ditampilkan oleh/pada pihak ketiga atas persetujuan sepanjang masih terkait dengan tujuan perolehan dan pengumpulan data pribadi; memberikan akses atau kesempatan kepada pemilik data pribadi untuk mengubah atau memperbarui data pribadinya tanpa menganggu sistem pengelolaan data pribadi, kecuali ditentukan lain oleh ketentuan peraturan perundangundangan; memusnahkan data pribadi sesuai dengan ketentuan dalam Peraturan Menteri ini atau ketentuan peraturan perundangundangan lainnya yang secara khusus mengatur di masing-masing instansi pengawas dan pengatur sektor untuk itu; dan menyediakan narahubung

15 Bandingkan Pasal 27 Perkominfo No. 20 Tahun 2016. 
(contact person) yang mudah dihubungi oleh pemilik data pribadi terkait pengelolaan data pribadinya.

Setiap pihak yang memperoleh, mengumpulkan, mengolah, menganalisis, menyimpan, menampilkan, mengumumkan, mengirimkan dan/atau menyebarluaskan data pribadi tanpa hak atau bertentangan dengan peraturan ini serta peraturan perundangundangan yang lain akan dikenakan sanksi administratif berupa peringatan lisan, peringatan tertulis, penghentian sementara kegiatan dan/ atau pengumuman di situs dalam jaringan (website online). ${ }^{16}$

b. POJK No. 13/POJK.02/ 2018 tentang Inovasi Keuangan Digital di Sektor Jasa Keuangan

Menurut POJK ini, penyelenggara bisnis Fintech wajib menjaga kerahasiaan, keutuhan, dan ketersediaan data pribadi, data transaksi dan data keuangan yang dikelolanya sejak data diperoleh hingga data tersebut dimusnahkan. ${ }^{17}$ Syarat pemanfaatan data dan informasi pengguna antara lain: 18

1) memperoleh persetujuan dari pengguna;

2) menyampaikan batasan pemanfaatan data dan informasi kepada pengguna;

3) menyampaikan setiap perubahan tujuan pemanfaatan data dan informasi kepada pengguna dalam hal terdapat perubahan tujuan pemanfaatan data dan informasi; dan

4) media dan metode yang digunakan dalam memperoleh data dan informasi terjamin kerahasiaan, keamanan serta keutuhannya.
Dalam Pasal 31, penyelenggara diwajibkan untuk menerapkan prinsip dasar perlindungan konsumen yaitu: transparansi, perlakuan yang adil, keandalan, kerahasiaan dan keamanan data/informasi konsumen, penanganan pengaduan serta penyelesaian sengketa konsumen secara sederhana, cepat dan biaya terjangkau. Selain itu, penyelenggara juga wajib menyediakan pusat pelayanan konsumen berbasis teknologi yang paling sedikit terdiri atas penyediaan pusat layanan konsumen yang dapat dilaksanakan sendiri atau melalui pihak lain. Selain kewajiban yang disebutkan dalam Pasal 31, penyelenggara memiliki kewajiban lain yakni menyediakan dan/atau menyampaikan informasi terkini kepada OJK dan konsumen mengenai aktivitas layanan keuangan digital. Informasi tersebut dituangkan dalam dokumen atau sarana lain yang dapat digunakan sebagai alat bukti.

Pasal 39 mengatur bahwa setiap pihak yang melanggar atau menyebabkan pelanggaran terhadap POJK ini akan dikenakan sanksi administratif berupa peringatan tertulis, kewajiban membayar denda dalam bentuk uang, pembatalan persetujuan dan/atau, pembatalan pendaftaran. Sanksi yang dikenakan OJK ini tidak mengurangi ketentuan pidana di sektor jasa keuangan. Selain sanksi administratif, Pasal 40 mengatur bahwa OJK dapat melakukan tindakan tertentu terhadap pelanggaran POJK ini.

16 Bandingkan Pasal 36 Perkominfo No. 20 Tahun 2016. 


\section{c. POJK No. 77 /POJK.01/ 2016 tentang Layanan Pinjam Meminjam Uang Berbasis Teknologi Informasi}

Perlindungan data konsumen yang berkaitan dengan data pribadi di atur dalam Pasal 26. Pasal tersebut mewajibkan penyelenggara untuk menjaga kerahasiaan data pribadi pengguna jasa. Kemudian Pasal 29 mengatur bahwa penyelenggara wajib menerapkan prinsip dasar perlindungan pengguna yaitu transparansi, perlakuan yang adil, keandalan, kerahasiaan dan keamanan data serta penyelesaian sengketa pengguna secara sederhana, cepat dan biaya terjangkau.

Selain kewajiban, penyelenggara juga dilarang untuk memberikan data dan/atau informasi mengenai pengguna kepada pihak ketiga dengan cara apapun kecuali pengguna memberikan persetujuan secara elektronik dan/atau karena diwajibkan oleh ketentuan peraturan perundangundangan. Apabila penyelenggara melanggar kewajiban dan larangan dalam POJK ini, maka akan dikenakan sanksi administratif. Sanksi tersebut berupa peringatan tertulis, kewajiban membayar denda dalam bentuk uang, pembatasan kegiatan usaha dan pencabutan izin.

d. POJK No. 1/POJK.07/2013 tentang Perlindungan Konsumen Sektor Jasa Keuangan

Pasal 2 mengatur mengenai prinsip dari perlindungan konsumen yang harus disediakan bagi konsumen, termasuk didalamnya konsumen Fintech sebagai pengguna jasa keuangan. Prinsip tersebut adalah transparansi, perlakuan yang adil, keandalan, kerahasiaan dan keamanan data/ informasi konsumen, penanganan pengaduan serta penyelesaian sengketa konsumen secara sederhana, cepat dan biaya terjangkau. Selanjutnya Pasal 31 mengatur mengenai larangan yang berkaitan dengan data konsumen bagi Pelaku Usaha Jasa Keuangan (selanjutnya disebut PUJK). Larangan tersebut adalah tidak memberikan data dan/atau informasi mengenai konsumennya kepada pihak ketiga dengan cara apapun kecuali dengan ijin tertulis dari konsumen dan atau karena diwajibkan oleh peraturan perundang-undangan. Selain larangan, Pasal 49 juga mewajibkan PUJK memiliki dan menerapkan kebijakan dan prosedur tertulis perlindungan konsumen. Kebijakan tersebut wajib dituangkan dalam standar prosedur operasional yang kemudian dijadikan panduan dalam seluruh kegiatan operasional PUJK.

Pelanggaran terhadap POJK ini akan dikenakan sanksi administratif sebagaimana yang dimaksud dalam Pasal 53. Sanksi administratif tersebut berupa: peringatan tertulis, denda untuk membayar sejumlah uang tertentu, pembatasan kegiatan usaha, pembekuan kegiatan usaha dan pencabutan izin kegiatan usaha.

Selain POJK ini, pengaturan secara khusus mengenai Fintech oleh OJK bisa ditemukan dalam Surat Edaran Otoritas Jasa Keuangan No. 14/ SEOJK.07/2014 tentang Kerahasiaan dan Keamanan Data dan/atau Informasi Pribadi Konsumen dan Surat Edaran Otoritas Jasa Keuangan Nomor 18 /SEOJK. 02/2017 tentang Tata Kelola dan Manajemen Risiko Teknologi Informasi Pada Layanan Pinjam Meminjam Uang Berbasis Teknologi Informasi. 


\section{Hubungan Hukum Para Pihak dalam Bisnis Fintech}

Hubungan hukum merupakan hubungan yang terhadapnya hukum meletakan hak pada satu pihak dan meletakan kewajiban pada pihak lain. ${ }^{19}$ Para pihak dalam bisnis Fintech secara umum adalah penyelenggara bisnis Fintech, yaitu setiap pihak yang menyelenggarakan bisnis Fintech dan pengguna Fintech, yaitu setiap pihak yang menggunakan LJK berbasis teknologi informasi atau elektronik. Hubungan hukum para pihak dalam bisnis Fintech adalah hubungan yang terhadapnya hukum meletakan hak pada pihak pengguna Fintech dan meletakan kewajiban pada pihak lain yaitu penyelenggara bisnis Fintech, begitu pula sebaliknya.

Hubungan hukum para pihak dalam bisnis Fintech muncul karena adanya suatu perjanjian, ${ }^{20}$ yaitu perjanjian elektronik. Bisnis Fintech menggunakan media elektronik dalam menjalankan kegiatan usahanya yaitu memberikan LJK kepada konsumen, sehingga perjanjian yang dibuat oleh para pihak pun adalah perjanjian elektronik. Hubungan hukum dalam bisnis Fintech mengikat bagi para pihak ketika disetujuinya suatu perjanjian elektronik. Penyelenggara Fintech, menawarkan produk dan layanannya disertai dengan berbagai informasi seperti harga, spesifikasi barang, nilai rating produk atau jasa perusahaan pembuat dan lain-lain kepada konsumennya secara online.

Penerimaan (acceptance) adalah suatu komunikasi yang dilakukan oleh pihak yang ditawarkan sesuatu (offeree) kepada pihak yang menawarkan sesuatu (offeror) di mana rangkaian kata-kata atau tindakan yang dilakukan secara objektif dapat diterjemahkan atau diartikan menyetujui penawaran (offer). Pengguna melakukan penerimaan terhadap penawaran dalam bisnis Fintech secara elektronik yaitu melaluai e-mail atau webpage. Dalam hal ini perusahaan Fintech melalui websitenya telah menyediakan formulir jasa keuangan atau produk keuangan yang bisa diisi secara langsung oleh calon konsumen sesuai dengan yang dibutuhkan atau calon konsumen diharuskan untuk terlebih dahulu membuka akun atau mendaftarkan diri menjadi anggota sebelum kemudian mendapatkan formulir dan melakukan verifikasi data dan approval melalui e-mail. ${ }^{21}$

Suatu kontrak elektronik sah apabila memenuhi Pasal 47 ayat (2), Peraturan Pemerintah No. 82 Tahun 2012 tentang Penyelenggaraan Sistem dan Transaksi Elektronik, yaitu:

1) terdapat kesepakatan para pihak;

2) dilakukan oleh subjek hukum yang cakap atau yang berwenang mewakili sesuai dengan ketentuan peraturan perundang-undangan

3) terdapat hal tertentu; dan

4) objek transaksi tidak boleh bertentangan dengan peraturan perundang-undangan, kesusilaan dan ketertiban umum.

Syarat sahnya perjanjian elektronik ini sejalan dengan ketentuan Pasal 1320 KUHPerdata. Perjanjian elektro-

\footnotetext{
19 Titik Triwulan Tutik, Hukum Perdata dalam Sistem Hukum Nasional (Kencana 2008) 201.

20 E. Santi, B. Budiharto \& H. Saptono 'Pengawasan Otoritas Jasa Keuangan Terhadap Financial Technology (Peraturan Otoritas Jasa Keuangan Nomor 77/POJK. 01/2016)' (2018) 6 Diponegoro Law Journal 1, 13.

21 Ibid.
} 
nik dalam bisnis Fintech berisi hak dan kewajiban para pihak. Berdasarkan Pasal 30 POJK No. 13 Tahun 2018, kewajiban yaitu: penyelenggara wajib menjaga kerahasiaan, keutuhan dan ketersediaan data pribadi, data transaksi dan data keuangan yang dikelolanya sejak data diperoleh hingga data tersebut dimusnahkan; pemanfaatan data dan informasi pengguna yang diperoleh penyelenggara harus memperoleh persetujuan dari pengguna, menyampaikan batasan pemanfaatan data dan informasi kepada pengguna, menyampaikan setiap perubahan tujuan pemanfaatan data kepada pengguna dalam hal ada perubahan tujuan pemanfaatan data, media dan metode yang dipergunakan dalam memperoleh data dan informasi terjamin kerahasiaan, keamanan, serta keutuhannya. Penyelenggara Fintech berhak untuk memastikan adanya itikad baik konsumen dan mendapatkan informasi dan/atau dokumen mengenai konsumen yang akurat, jujur, jelas dan tidak menyesatkan. Berdasarkan penelusuran yuridis tidak ada pengecualian yang dapat ditetapkan pihak produsen terhadap kewajiban menjaga kerahasiaan data pribadi konsumennya. Artinya apabila produsen tidak melakukan kewajibannya tersebut maka ia telah melakukan perbuatan melawan hukum dan bisa dimintakan pertanggungjawabannya.

Sedangkan kewajiban dari pengguna jasa konsumen Fintech adalah memberikan data atau informasi pribadi yang benar kepada penyeleng- gara bisnis Fintech, dengan cara mengisi formulir elektronik yang telah disediakan penyelenggara dengan data pribadi yang benar. Hak konsumen Fintech adalah mendapatkan LJK yang ditawarkan oleh produsen Fintech dan mendapatkan jaminan perlindungan hukum atas keamanan data pribadi yang telah diserahkan kepada penyelenggara Fintech.

\section{Perlindungan Hukum Terhadap Keamanan Data Konsumen dalam Bisnis Fintech}

Salah satu sifat sekaligus tujuan hukum itu adalah memberikan perlindungan (pengayoman) kepada masyarakat. ${ }^{22}$ Hukum merupakan sarana mutakhir dalam mengendalikan berbagai perubahan di masyarakat sehingga perubahan yang ada mampu juga mewujudkan pembangunan bangsa dan negara ke arah yang lebih positif. ${ }^{23}$ Hukum mampu memberikan solusi atas kemungkinan penggunaan dan pemanfaatan iptek untuk sebesar-besarnya kemanfaatan dan kelangsungan hidup manusia, ${ }^{24}$ dalam konteks Fintech, salah satu tujuan hukum adalah untuk melindungi konsumen. Perlindungan hukum adalah memberikan pengayoman kepada hak asasi manusia yang dirugikan orang lain dan perlindungan tersebut diberikan kepada masyarakat agar mereka dapat menikmati semua hak-hak yang diberikan oleh hukum. ${ }^{25}$ Apabila konsumen itu adalah masyarakat,

22 Bambang Eko Turisno, 'Perlindungan Konsumen dalam Iklan Obat' (2012) 41 Jurnal Masalah-Masalah Hukum 20, 28.

23 Esmi Warassih, 'Peran Politik Hukum Dalam Pembangunan Nasional' (2018) 5 Jurnal Gema Keadilan 1, 12.

24 Sri Redjeki Hartono, 'Perspektif Hukum Bisnis Pada Era Teknologi' (Pidato Pengukuhan Guru Besar Universitas Diponegoro, 1995).

25 Satjipto Raharjo, Ilmu Hukum (PT Citra Aditya Bakti 2006) 20. 
artinya melindungi konsumen berarti juga melindungi masyarakat. ${ }^{26}$ Salah satu bentuk perlindungan hukum terhadap konsumen Fintech adalah perlindungan terhadap keamanan data pribadinya.

Berdasarkan konsep privasi yang dikemukakan oleh Thomas J. Imedinghaff, salah satu konsep privasi yaitu privasi dari data tentang seseorang (privacy of data about person), yang artinya hak privasi dapat juga mengikat pada informasi mengenai seseorang yang dikumpulkan dan digunakan oleh orang lain. ${ }^{27}$ Berangkat dari konsep "privacy of data about person" maka kita ketahui bahwa perlindungan terhadap keamanan data pribadi merupakan perwujudan dari privasi seseorang sehingga sangat penting untuk diwujudkan.

Perlindungan data pada dasarnya dapat berhubungan secara khusus dengan privasi seperti yang dikemukakan oleh Allan Westin yang untuk pertama kali mendefinisikan privasi sebagai hak individu, grup atau lembaga untuk menentukan apakah informasi tentang mereka akan dikomunikasikan atau tidak kepada pihak lain sehingga definisi yang dikemukakan oleh Westin disebut dengan information privacy karena menyangkut informasi pribadi. 28 Pendapat Westin ini apabila kita bawa dalam konteks bisnis Fintech yang berkembang pesat di tengah lajunya perkembangan teknologi informasi, bisa dipahami bahwa data pribadi perlu dilindungi karena data pribadi merupakan bagian dari privasi individu, sehingga pemilik data pribadi itu sendirilah yang menentukan apakah data pribadinya boleh diakses dan diketahui oleh orang lain atau tidak. Artinya segala data pribadi tesebut apabila pihak lain ingin mengetahuinya harus dengan persetujuan pemilik data pribadi.

Keberadaan OJK sebagai lembaga pengawas di sektor jasa keuangan, diharapkan mampu melindungi konsumen dari PUJK yang dinilai dapat merugikan kepentingan konsumen, dalam hal ini konsumen Fintech. OJK sebagai lembaga yang memiliki kewenangan mengawasi kegiatan usaha di sektor jasa keuangan, harus mampu melindungi konsumen pengguna jasa keuangan yang menempatkan dananya dan/atau memanfaatkan pelayanan yang tersedia di lembaga jasa keuangan. Dalam penelitian ini khususnya adalah konsumen Fintech. Hal ini seperti ditentukan dalam Pasal 4 huruf c UU No. 21 Tahun 2011 tentang Otoritas Jasa Keuangan yang menyatakan bahwa salah satu tujuan dibentuknya OJK adalah agar dapat melindungi kepentingan konsumen dan masyarakat dalam di sektor jasa keuangan. Perlindungan ini dimaksudkan agar dapat memberikan rasa aman terhadap konsumen sebagai pengguna jasa keuangan. Konsumen Fintech sebagai pengguna jasa keungan memiliki hak untuk mendapatkan perlindungan atas data pribadinya pada perusahaan Fintech yang memberikan jasa keungan kepadanya.

Oleh karena itu, OJK melalui Surat Edaran Otoritas Jasa Keuangan No. 14/SEOJK.07/2014 tentang

\footnotetext{
26 Janus Sidabalok, Hukum Perlindungan Konsumen di Indonesia (Citra Aditya Bakti 2010) 3.

27 Thomas J. Imedinghaff, ed., Online Law The SPA's Legal Guide to Going Business on The Internet (Addison-wesley Developers Press 1996) 269. Dalam Edmon Makarin, Pengantar Hukum Telematika (PT. Raja Grafindo Persada 2005) 160. 
Kerahasiaan dan Keamanan Data dan/atau Informasi Pribadi Konsumen, data pribadi yang harus dilindungi dalam bisnis Fintech di Indonesia yaitu:

1) Data perseorangan, yang harus dilindungi: nama, alamat, tanggal lahir dan/atau umur, nomor telepon, dan/atau nama ibu kandung.

2) Data korporasi, yang harus dilindungi: nama, alamat, nomor telepon, susunan direksi dan komisaris termasuk dokumen identitas berupa Kartu Tanda Penduduk (KTP)/paspor/ijin tinggal, dan/atau susunan pemegang saham.

Sedangkan menurut Surat Edaran Otoritas Jasa Keuangan No. 18 /SEOJK.02/2017, data pribadi yang harus dilindungi yaitu:

1) Perseorangan seperti: nama, alamat domisili, kartu identitas (KTP, Surat Ijin Mengemudi (SIM), paspor), Nomor Pokok Wajib Pajak (NPWP), tanggal lahir dan/atau umur, alamat email, IP address, nomor telepon, nomor rekening, nama ibu kandung, nomor kartu kredit, identitas digital (biometrik), tanda tangan, riwayat pendidikan, riwayat pekerjaan, rekening koran, daftar harta kekayaan, data dan informasi terkait lainnya.

2) Korporasi: nama korporasi, alamat, nomor telepon, susunan direksi dan komisaris termasuk dokumen identitas berupa KTP/ paspor/izin tinggal, susunan pemegang saham, nomor rekening, rekening koran, daftar aset, dokumen perusahaan, data dan informasi terkait lainnya.

3) Data dan informasi non-publik yang bersifat material: laporan keuangan, kinerja usaha, keputusan manajemen, jumlah pelanggan, data dan informasi terkait lainnya.

4) Data dan informasi terkait transaksi keuangan.

5) Data dan informasi terkait kontrak/perjanjian.

\section{PENUTUP}

Berdasarkan hasil penelitian, para pihak dalam bisnis Fintech terdiri dari penyelenggara bisnis Fintech atau produsen dan pengguna Fintech atau konsumen. Hubungan para pihak dalam bisnis Fintech terjadi karena adanya perjanjian elektronik yaitu perjanjian yang dibuat dengan media elektronik. Perjanjian elektronik berisi hak dan kewajiban para pihak dalam bisnis Fintech. Kewajiban penyelenggara Fintech yaitu wajib menjaga kerahasiaan, keutuhan dan ketersediaan data pribadi, data transaksi, dan data keuangan yang dikelolanya sejak data diperoleh hingga data tersebut dimusnahkan. Pemanfaatan data dan informasi pengguna yang diperoleh penyelenggara harus memperoleh persetujuan dari pengguna, menyampaikan batasan pemanfaatan data dan informasi kepada pengguna, menyampaikan setiap perubahan tujuan pemanfaatan data dan infomasi kepada pengguna dalam hal terdapat perubahan tujuan pemanfaatan data dan informasi, media dan metode yang dipergunakan dalam memperoleh data dan informasi terjamin kerahasiaan, keamanan, serta keutuhannya. Penyelenggara Fintech berhak untuk memastikan adanya itikad baik konsumen dan mendapatkan informasi dan/atau dokumen mengenai konsumen yang akurat, jujur, jelas, dan tidak menyesatkan. Kewajiban dari konsu- 
men Fintech adalah memberikan data atau informasi pribadi yang benar kepada penyelenggara bisnis Fintech, dengan mengisi formulir elektronik yang telah disediakan penyelenggara dengan data pribadi yang benar. Hak dari konsumen Fintech adalah mendapatkan LJK yang ditawarkan oleh penyelenggara produsen Fintech, dan mendapatkan jaminan perlindungan hukum atas keamanan data pribadi yang telah diserahkan kepada penyelenggara Fintech.

Perlindungan hukum terhadap data pribadi konsumen Fintech diatur oleh Kemkominfo RI melalui Peraturan Menkominfo No. 20 Tahun 2016, oleh OJK melalui POJK No. 77 Tahun 2016, POJK No. 13 Tahun 2018 serta peraturan pelaksananya, yaitu Surat Edaran OJK. Data yang harus dilindungi:

1) Data pribadi perseorangan.

2) Data pribadi korporasi.

3) Data dan informasi non-publik yang bersifat material.

4) Data dan informasi terkait transaksi keuangan.

5) Data dan informasi terkait kontrak/perjanjian.

Perlindungan data pribadi merupakan salah salah satu bentuk hak privasi yang merupakan hak individu sehingga harus dijamin negara. Konsep perlindungan data pribadi mengisyaratkan bahwa individu memiliki hak untuk menentukan berbagi data pribadinya atau tidak. Hak privasi melalui perlindungan data pribadi sangat penting dan bahkan merupakan elemen kunci bagi kebebasan dan harga diri individu. Perlindungan data pribadi merupakan pendorong kuat bagi terwujudnya kebebasan politik, spiritual, keagamaan, bahkan kegiatan seksual. Hak untuk menentukan nasib sendiri, kebebasan berekspresi dan privasi adalah hak-hak yang penting untuk menjadikan kita sebagai manusia. Dalam kaitannya dengan bisnis Fintech, data pribadi konsumen Fintech inilah yang harus dilindungi. Apabila terjadi pembocoran atas data pribadi konsumen ini maka sanksi yang telah diatur dalam Peraturan Menkominfo RI dan POJK yang telah dijelaskan sebelumnya bisa dikenakan kepada pihak yang membocorkan data pribadi konsumen tersebut.

Saran yang dapat diajukan adalah OJK harus merevisi POJK tentang perlindungan konsumen di sektor jasa keuangan, yaitu Pasal 1. Pasal 1 ini menurut hemat penulis belum mencakup penyelenggara jasa keuangan digital yaitu Fintech, sehingga harus dilengkapi. OJK juga harus merevisi POJK tentang Layanan Pengaduan Konsumen Sektor Jasa Keuangan yang harus direvisi yaitu Pasal 1, Pasal 1 ini menurut penulis belum lengkap karena jenis bisnis Fintech yang masuk dalam ketentuan tersebut hanya layanan simpan pinjam berbasis TI, sedangkan menurut hasil penelitian penulis jenis bisnis Fintech tidak hanya layanan simpan pinjam berbasis teknologi informasi saja.

Penyelenggara LJK digital harus mentaati peraturan mengenai penyelenggaraan layanan keuangan digital yang dikeluarkan oleh pemerintah (BI, OJK, Kemkominfo RI). Penyelenggara juga harus menerapkan prinsip perlindungan konsumen, dan harus menerapkan asas itikad baik dalam setiap tindakannya kepada konsumen dalam melakukan kegiatan usahanya.

Pengguna Fintech harus memastikan apakah penyelenggara itu sudah terdaftar di OJK atau belum, apabila belum sebaiknya jangan ditanggapi. 
Pengguna jangan memberikan data apapun kepada penyelenggara apabila belum diketahui status hukumnya. Apabila membuat suatu perjanjian dengan penyelenggara harus dibaca dan dipahami setiap klausul perjanjian tersebut, apabila dirasa memberatkan lebih baik tidak disetujui. Penulis berharap hasil penelitian ini bisa memberikan pencerahan terhadap setiap pembaca mengenai pentingnya perlindungan hukum terhadap keamanan data pribadi konsumen khususnya konsumen Fintech di Indonesia.

\section{DAFTAR BACAAN}

\section{Buku}

Imedinghaff, Thomas J., ed., Online Law The SPA's Legal Guide to Going Business on The Internet ( (Addison-wesley Developers Press 1996).

Makarin, E., Pengantar Hukum Telematika (PT. Raja Grafindo Persada 2005).

OJK, Kajian Perlindungan Konsumen Sektor Jasa Keuangan: Perlindungan Konsumen Pada Fintech (Departemen Perlindungan Konsumen OJK 2017).

Raharjo, S., Ilmu Hukum (PT Citra Aditya Bakti 2006).

Sidabalok, J., Hukum Perlindungan Konsumen di Indonesia (Citra Aditya Bakti 2010).

Tutik, Titik T., Hukum Perdata dalam Sistem Hukum Nasional (Kencana 2008).

Westin, Alan F., Privacy and Freedom (London 1967).

\section{Artikel Jurnal}

Abubakar, L., \& Handayani, T., 'Financial Technology: Legal Challenges for Indonesia Financial Sector' (2018) 175 IOP Publishing.

Arief, Nawawi B., 'Kebijakan Penanggulangan Cyber Crime dan Cyber Sex' (2006) 1 Law Reform.

Basuki, F. H., \& Husein, H., 'Analisis SWOT Financial Technology Pada Dunia Perbankan Di Kota Ambon' (2018) 2 Manajemen dan Bisnis.

Chrismastianto, Imanuel Adhitya W., 'Analisis SWOT Implementasi Tekonologi Finansial terhadap Kualitas Layanan Perbankan di Indonesia' (2017) 20 Jurnal Ekonomi Dan Bisnis.

Margaretha, F., 'Dampak Elektronik Banking Terhadap Kinerja Perbankan Indonesia' (2015) 19 Jurnal Keuangan dan Perbankan.

P., Buckley R., and S., Webster., 'FinTech in Developing Countries: Charting New Customer Journeys J Capco Inst J Financ Transform' (2018) 44 Journal of Financial Transformation.

Raharjo, A., \& Sudrajat, T. (Eds.), 'Fintech Indonesia User Legal Protection in Balance Borrowing Money Based on Information Technology' (2018) 54 SHS Web of Conferences.

Santi, E., Budiharto, B., \& Saptono, H., 'Pengawasan Otoritas Jasa Keuangan Terhadap Financial Technology (Peraturan Otoritas Jasa Keuangan Nomor 77/POJK. 01/2016)' (2018) 6 Diponegoro Law Journal. 
Turisno, Bambang E., 'Perlindungan Konsumen dalam Iklan Obat' (2012) 41 Masalah-Masalah Hukum.

Warassih, E., 'Peran Politik Hukum Dalam Pembangunan Nasional' (2018) 5 Gema Keadilan.

\section{Internet}

Sugianto, D., 'Transaksi Fintech di Indonesia Tembus Rp 26 Triliun' (2019) <https:// finance.detik.com /berita-ekonomi-bisnis/d-444588 $0 /$ transaksi-fintech-di-indonesiatembus-rp-26-triliun> diakses 28 Februari 2019.

Publikasi OJK, 'Penyelenggara Fintech Terdaftar di OJK per Februari 2019' (2019) <https://www.ojk .go.id/id/berita-dan-kegiatan/pu blikasi/Pages / Penyelenggara-Fint ech-Terdaftar-di-OJK-per-Februa ri-2019.aspx> diakses 28 Februari 2019.

Publikasi OJK, 'Penyelenggara Fintech Terdaftar di OJK per Desember 2018' (2018) <https://www.ojk .go.id/id/berita-dan-kegiatan/pu blikasi/Pages/Penyelenggara-Fint ech-Terdaftar-di-OJK-per-Desemb er-2018.aspx> diakses 21 Januari 2019.

\section{Peraturan Perundang-Undangan}

Undang-Undang Nomor 19 Tahun 2016 tentang Perubahan Atas Undang-Undang Nomor 11 Tahun 2008 tentang Informasi dan Transaksi Elektronik.

Peraturan Pemerintah Nomor 82 Tahun 2012 tentang Penyelenggaraan Sistem dan Transaksi Elektronik.

Peraturan Bank Indonesia Nomor 19/12/PBI/ 2017 tentang Penyelenggaraan Teknologi
Finansial.

Peraturan Otoritas Jasa Keuangan Nomor 77 /POJK.01/2016 tentang Layanan Pinjam Meminjam Uang Berbasis Teknologi Informasi.

Peraturan Otoritas Jasa Keuangan RI Nomor 13 /POJK.02/2018 tentang Inovasi Keuangan Digital di Sektor Jasa Keuangan.

Peraturan Menteri Komunikasi dan Informatika Nomor 20 Tahun 2016 tentang Perlindungan Data Pribadi Dalam Sistem Elektronik.

Surat Edaran Otoritas Jasa Keuangan Nomor 14/SEOJK.07/2014 tentang Kerahasiaan dan Keamanan Data dan/atau Informasi Pribadi Konsumen.

Surat Edaran Otoritas Jasa Keuangan Nomor 18/SEOJK.02/2017 tentang Tata Kelola dan Manajemen Risiko Teknologi Informasi Pada Layanan Pinjam Meminjam Uang Berbasis Teknologi Informasi.

\section{Pidato Pengukuhan Guru Besar}

Hartono, Sri R., Perspektif Hukum Bisnis Pada Era Teknologi (Pidato Pengukuhan Guru Besar Universitas Diponegoro 1995). 
